Politics in Central Europe (ISSN: 1801-3422)

Vol. 12, No. 1

DOI: $10.1515 /$ pce-2016-0009

\title{
The Power of the Capability Constraint: On Russia's Strength in the Arctic Territorial Dispute
}

\author{
IRINA VALKO
}

\begin{abstract}
Based on a geographical-administrative definition of the region, the theoretical assumptions of contemporary French structuralist geopolitics, cross-sectional data for 1990, 1995, 2000, 2005 and 2010 from the Updated Arctic Regional Attributes Dataset, and the technical capabilities of MS Office Excel 2010, this research (a) reveals and contrasts the Arctic states' capability constraints deriving from their longitudinal material and virtual power potential (physical potential, socio-economic potential, military potential, and symbolic potential); and (b) analyses the role of this constraint in the process of preference formation in case of one specific Arctic actor, Russia, in the Arctic territorial dispute. This study confirms that Russia's capability constraint is the lowest in the region and that the latter does not form a stable trend throughout the period studied. It also suggests the preference formation framework for Russia in the Arctic dispute based on the evolution of its polar capability constraint.
\end{abstract}

Keywords: Russia, the Arctic, geopolitical analysis, power, capability constraint, regional strategy

\section{Introduction: On Russia's Role in the Arctic Territorial Dispute}

The Arctic region has recently started a new era of continuous natural- and human-related transition. Firstly, the unprecedented and continuously increasing rate at which the polar multiyear ice has been melting is one of the stable characteristics of the beginning of the twenty-first century. Secondly, similarly to the Antarctic, the emergence of the Arctic as a distinct international region has, in fact, been the most recent among all global regions. Consequently, histori-

1 Work on this article was supported by Specific Academic Research project of the Institute of Political Studies, Faculty of Social Sciences, Charles University, Prague, no. 260230 / 2015 „Proměny a důsledky politických instituci" ["Changes and impacts of political institutions"], Charles University in Prague, Faculty of Social Sciences, Institute of Political Studies.

The author would like to thank the two anonymous reviewers for their comments that contributed to improving the final version of this research. 
cal factors have had a minimal effect in the Arctic. Throughout most of the $20^{\text {th }}$ century the northernmost region was an exclusively military-strategic location within the Cold-War system of international politics. However, today the Arctic is becoming more and more 'attractive' to the global community due to its economic potential. Thirdly, with the exception of Japan, all major global players of the Northern Hemisphere (the United States, Canada, the European Union, and Russia) are active participants in the intraregional strategic dialogue. Finally, the shrinking of the polar sea ice in rendering the Northwest Passage and the Northern Sea Route more attractive for global maritime trade network logistics.

Four states within the 'Arctic Eight' group ${ }^{2}$ have been continuously signalling the desire to extend their own outer limits of the northernmost continental shelves in the central part of the Arctic Ocean: Canada, Denmark, Russia and the United States. However, only two of them, Russia and Denmark, have already provided specific coordinate points delimiting the area to the United Nations Commission on the Limits of the Continental Shelf (CLCS). These two states are the initiator decision makers, because they are attempting to change the status quo. ${ }^{3}$ Although, in legal terms, neither Canada nor the United States has an active Arctic claim, their territorial aspirations are routinely replicated in political maps delimiting their sovereignty claims in the Central Arctic Ocean by a range of cartographic agencies ${ }^{4}$ and news channels ${ }^{5}$ and their strategic situation is part of the current analysis as well.

There is significant overlap in the existing northernmost territorial claims in two areas next to the geographic North Pole where the Russian claim intersects with the Danish claim and the potential Canadian claim. ${ }^{6}$ In terms of the relationship of these countries with the international community ${ }^{7}$ (the third,

2 Canada, Denmark, Finland, Iceland, Norway, Russia, Sweden and the United States - countries whose land and/or water territories currently lie within the Arctic Circle.

3 This study is based on the (still dominant) state-centric approach: the governments-in-power of the Arctic states signaling their intention to extend their own sovereignty in the Central Arctic Ocean are viewed as the definite actors of international relations - the final decision-makers in the judicial sense.

4 Among others, IBRU, Map of Arctic sovereignty claims (2015): <https://www.dur.ac.uk/ibru/resources/ arctic>.

5 Among others, BBC, Denmark challenges Russia and Canada over North Pole (2014): <http://www.bbc. com/news/world-europe-30481309>.

6 In December, 2014, Denmark made an official claim to the United Nations Convention on the Law of the Sea (UNCLOS) over some 900 thou. sq. km of the ocean north of Greenland, thus extending the claim under the original sector approach ('stopping' at the North Pole) deep into the Russian sector. In this case the intersection of the Danish and Russian claims is significant - see the updated Arctic dispute graphics at: <http://www.economist.com/news/international/21636756-denmark-claims-north-pole-frozen-conflict> However, given the timing of the event (post-Crimea), we may believe that by doing so, Denmark tries to raise the stakes in order to make concessions in the later stages of negotiations a frequent strategy in business and diplomacy (Malhotra 2006:1+).

7 The rest of the "Arctic Eight" group (Canada, the United States, Finland, Sweden, Norway, and Iceland), more than twenty non-Arctic states demonstrating readiness to invest in the commercial development of the region, and even countries that are, so far, not interested at all in the Arctic - "mankind". 
cumulative player in the dispute) with regard to whether the latter would agree to an almost full 'seizure' of the Arctic by just several countries, with Russia alone aiming to acquire almost one third of it, the stakes are expected to be high. A number of provocative manoeuvres have already been systematically occurring, including the planting of a one-meter-high titanium Russian flag on the underwater Lomonosov ridge, which Moscow claims to be directly connected to its own continental shelf, in 2007.

Because of alternative interpretations of the topographic reality (e.g. whether the Lomonosov ridge is truly a continuation of the continent), and since the actors may or may not intend to act in the same way (e.g. form a functional coalition), the dispute may have a range of outcomes, starting with the preservation of the status quo by recalling one's own submitted claim, and ending with the unilateral seizure of all claimed areas by the claimant states. ${ }^{8}$ Because a potential intraregional dispute over the location of the northernmost maritime borders might be resolved either peacefully or by force, it is important to know what capability constraint faces each player in the process of its regional preference construction.

Aside from a number of theme-specific reports by international (mostly environmentally-oriented) organizations, the majority of research incorporates either an actor-oriented perspective or a structure-oriented perspective while analysing the probability of conflict in the region. In both cases, the research either focuses on variables describing the Arctic geographic space (Dowdeswell and Hambrey 2002, Woodford 2003, Stein 2008), evaluates the effectiveness of regional cooperation attempts (Chaturvedi 1996, Exner-Pirot 2012, Hough 2013), or summarizes the expected geopolitical implications from the changing environment (Chapman 2011, Ostreng et al. 2013). With the exception of a comprehensive empirical introduction to the geopolitical functioning of the Arctic system by Knell (2008), draft scenarios of the region's development in the near future by Brigham (since 2007), and game-theoretic treatment of regional geopolitics by Cole, Izmalkov and Sjöberg (2014), a formal, quantitative method to define Russia's Arctic strategy according to the distribution of its hard and soft power - and classify the major geopolitical risks and opportunities for the actors based on these preferences - is still missing in the literature. This study aims to contribute to the ongoing geopolitical research, polar studies and Russian foreign policy analysis by:

a. providing longitudinal empirical evidence for the development of geopolitical power equilibria in the Arctic region (1990 - 2010);

b. computing Russia's polar capability constraint and comparatively assessing it against that of other Arctic states;

8 Given three solution strategies (preserve status quo, compromise, or full seizure), if the two initiating decision makers do not form a full coalition, the Arctic sovereignty game has $3^{\wedge} 2=9$ options. 
c. identifying the strengths of Russia's Arctic strategy-making as implied by its polar capability constraint in order to be used as an input in resolution modelling in the regional territorial dispute.

In order to approach these goals the following (technical) questions should be answered: Do all Arctic actors face similar power constraints in the northernmost region? How strong is the difference in power potential and capability constraint between Russia and the other Arctic states? Is the distribution of power stable over time? How do the material and virtual power capabilities influence the formation of Russia's preferences in the region? The vast research on political geography/ geopolitics of the Polar Regions, whose popularity in research has almost tripled over the last decade, ${ }^{9}$ does not provide a clear answer to these questions. This research (a) allows for an understanding of the role of capability constraint in the process of regional policy preference formation and (b) offers a compact and neutral analytical framework to deal with the internal logic of the Arctic territorial dispute.

The study consists of a two-stage analysis. First, we identify and compare the capability constraint for each Arctic actor. Second, we construct Russia's preferences in the Arctic territorial dispute based on its polar capability constraint. Two hypotheses are tested:

$\mathrm{H}_{1}$. Russia's capability constraint in the Arctic sovereignty game is the lowest in the region.

$\mathrm{H}_{2}$. Russia's capability constraint forms a stable trend throughout the studied period (1990-2010).

The work is structured as follows: in the next section we define capability constraint, introduce the nature of its role in the regional policy-building process and summarize the methodological configuration of the study. In the third section, following that, we present the dataset and the measurement procedure. The fourth section presents the results of the power index construction. The final section summarizes the main findings, evaluates the character of comparative advantage available to Russia in the Arctic sovereignty game as implied by its capability constraint, and suggests directions for further research.

9 Based on the average appearance of "Polar-", "Arctic-", "Antarctic-" and "Geopolitics" in Jstor, WoS and Questia platforms in 1990, 2000, and 2010. 


\section{Theoretical and Methodological Configuration}

If territory is disputed between sovereign nation states, it is usually indivisible: "the contest is necessarily a winner-take-all affair so that there is no room for compromise, probably leaving the dispute to devolve into a war of attrition. [...] Naturally, if there is not some way to compensate a player for a loss of this sort, the problem does not have a bargaining range. One side wins and the other loses" (Bueno de Mesquita 2010: 7). In other words, the territorial dispute over the central part of the Arctic Ocean is non-cooperative. In game-theoretic language, what options are available to Russia and other claimant states? What solutions are available in the Arctic territorial dispute?

For the largest part of the contested area, the United Nations Convention on the Law of the Sea (UNCLOS) ${ }^{10}$ provides a clear solution: a coastal state's maritime sovereignty decreases with increasing distance from the baseline and stops at 200 nautical miles $(\mathrm{nm})$ from the coast. In order to move the border further into the ocean, a claimant state must issue an application to the $\mathrm{CLCS}^{11}$ and provide it with supporting scientific and technical evidence that the border must be moved due to the existence of an adjacent 'submarine ridge'. In this case, public international law grants this state the right to extend its own sovereignty up to $350 \mathrm{~nm}$ from the baseline. But the $350 \mathrm{~nm}$ limit does not apply if the continental shelf is defined as a 'submarine elevation'. In other words, in order to extend its own border beyond $350 \mathrm{~nm}$, the coastal state must provide sound evidence that the Arctic undersea ridges are not ridges but elevations. However, the final decision on the location of the maritime boundary still rests on the claimant state. It is also the claimant state which performs surveillance and mapping, so there exists a relatively high risk that "... scientists will seek to interpret the data in a way that is as beneficial as possible for extended Continental Shelf claims while staying within what is scientifically credible" (Strandsbjerg 2012: 834).

The story becomes even more complicated with the fact that the Commission has no mandate to determine maritime boundaries between coastal states or to settle disputes unless the coastal states accept it. ${ }^{12}$ Keeping in mind that the United States has not ratified the Convention and, therefore, is still not bound by its provisions, the Commission's recommendations only relate to Norway, which, in turn, does not have an actual claim in the central part of the Arctic Ocean.

10 UNCLOS is an international treaty that provides a regulatory framework for the use of the world's seas and oceans, inter alia, to ensure the conservation and equitable usage of resources and the marine environment and to ensure the preservation of the living resources of the sea. The treaty has entered into force in 1994 and as of December 2014, 166 states have ratified, succeeded to, or acceded to, UNCLOS. The full text and status of the Convention can be found at: <http://www.un.org/depts/los/ convention_agreements/texts/unclos/closindx.htm>

11 Submissions are made through the Secretary-General of the United Nations (Article 76 of UNCLOS).

12 For a number of reasons, neither Denmark nor Russia accepts this. 
In the broader context of time-space geography, capability constraint can be defined as a limit to one's actions, either due to biological needs (such as hunger), or due to restricted facilities (such as landlockedness) ${ }^{13}$ In the realm of international politics, "...the most successful states... match their geostrategy to the underlying geopolitical reality" (Grygiel 2006:1). Russia's Arctic strategy formation is based on five underlying assumptions of strategy from a national perspective as described by H. Richard Yanger (2010). Firstly, strategy is proactive and anticipatory: it provides direction for the coercive or persuasive use of power to achieve specified objectives and this direction is, by nature, proactive. Secondly, the strategist knows the end state that (s)he is trying to achieve (i.e. to answer the question: What is to be accomplished?). Rational policy makers develop appropriate objectives leading to the desired end state and therefore analyse the desired end state in the context of the internal and external systemic environment. Thirdly, a rational strategist strives to optimize the balance between 'ends' (the objectives sought), 'ways' (methods to pursue the objectives), and 'means' (the resources available), so that an end is supported by concepts based on all the instruments of power and the associated resources. Fourthly, political purpose dominates all strategy, in the spirit of Karl Clausewitz' famous dictum: 'war is merely the continuation of policy by other means.' Policy is the expression of the desired end state sought by the decision makers. Objectives that lead to the desired end state provide purpose, focus, and justification for the actions embodied in a strategy. Finally, strategy is hierarchical: it cascades from the national level down to the lower levels. Political leadership ensures and maintains its control and influence through this hierarchy (Yarger 2010: 43-44).

In other words, rational players employ strategies which appropriately balance the objectives (ends), concepts for accomplishing objectives (ways), and resources for supporting these concepts (means). This is achieved by adding resources, using different concepts, or changing the objectives. According to Arthur Lykke, ends, ways, and means are three dimensions upon which the strategy rests. The logic is described through a 'chair metaphor', with the three legs of the 'strategy' chair - objectives (ends), concepts for accomplishing objectives (ways), and resources for supporting these concepts (means) - having the same height and diameter in order to minimize the risk of the chair falling after a 'heavy' national security is placed on it - see Figure 1 below. If any dimension is out of balance, the risk is too big and the strategy collapses (Lykke et al. 2001). In the Arctic sovereignty dispute, the level of relative superiority in material and virtual capabilities, whose derivative is the capability constraint, are considered to serve as the means each Arctic actor takes into consideration while building regional strategy. How are these individual capability constraints constructed?

13 See Golob and Regan (2001) and Axhausen in D. Ettema and H. Timmermans, eds. (1997). 


\section{Figure 1: The Lykke Model}

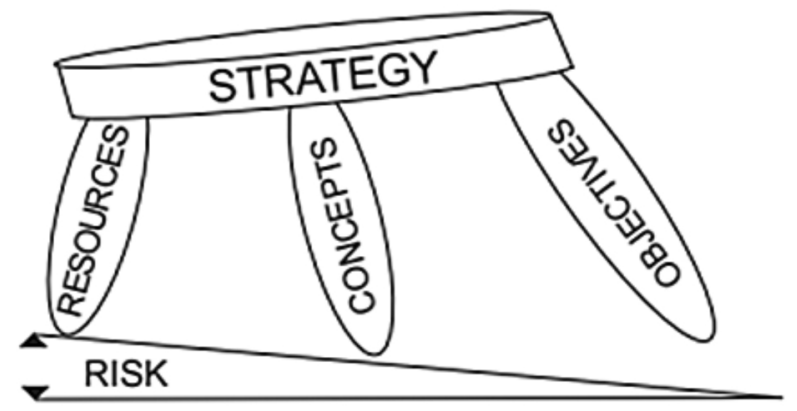

Source: Yarger 2010: 48.

The Arctic region is an open, complex geopolitical system. Its internal processes constitute a set of interconnected elements: changes in certain attributes (actors' material and virtual strength) imply ultimate changes elsewhere in the system. At the same time, the system is constantly interacting with the surroundings: both can adapt, and both are affected by the changing environment. Due to this complexity, any purely linear approach to the Arctic is inadequate because, as Niave Knell points out, "...it would not recognize the complexity and the second and third order effects of any one action... It is then necessary to study the system's dynamic [my emphasis] interaction of parts" (2008: 8).

Any research on the relations among states in the international system deals, to a lesser or a greater extent, with a structure-agency dilemma. ${ }^{14}$ Although this research accepts a certain complementarity of structure and agency, ${ }_{15}^{15}$ it focuses on agency and therefore reconstructs the actors' preferences in the Arctic dispute according to seventeen variables describing the regional geopolitical configuration - the actors' geographically- and socially-based capabilities.

At the same time, the analysis is positivist: the reality is considered to be external to human theories about it and it is assumed that the researcher's role is to solve problems and interpret the results without predetermined biases. However, it does not mean that the study is free of prejudice. It means that the scholar is aware of the potential dangers of this kind and chooses adequate research techniques to minimize them. A 'neutral' systemic framework significantly reduces the 'disturbances' arising from hidden biases related to the author's country of origin and cultural background. A quantitative and empiri-

14 Functionalists and Marxists believe that social life is primarily determined by social structure and that individual activities can be explained as an outcome of structure. In contrast, phenomenological sociologists and symbolic interactionists insist on the ability of individuals to construct and give meaning to social life.

15 While structure influences human behavior, individual activities similarly influence the social structure. 
cal character of research is based on a firm definition of all variables and strict rules of interaction between these variables. As a result, at this stage of research, each Arctic state enjoys the same degree of objective attention. ${ }^{16}$ Epistemologically, the analytical process is perceived through the prism of allocating the complex social reality (the whole) as a system of interconnected elements and then integrating these elements back into the whole as defined by Konstantin Plokhotnikov [1]:

$$
\text { Whole } \rightarrow \text { System of elements } \rightarrow \text { Whole' (2012: 18) }
$$

Gerard Dussouy's 'Global Interpretation Method of the World' (2010) 'translates' this version of systemic modelling into the language of geopolitical analysis. ${ }^{17}$ The idea is that "...no two-dimensional map can capture the multi-scalar intersection of physical, demographic, strategic, socio-economic, and cultural-ideological forces at work in the geopolitical arena; instead, we need to think in terms of the interaction of all these things in different places and under varying circumstances" (Murphy 2010: 151). The author contributes to the approach developed by the contemporary structuralist branch of the French school of geopolitics by segregating the global system into five distinct geopolitical action spaces: physical, natural space; demo-political space; diplomatic-military space; socio-economic space; and symbolic, idealistic and cultural space, with the first four forming the system's objective structure and the last one being its subjective component. The goal is then to analyse, spatially, the transforming tendencies within each of these spaces in order to extract the system's structural logic and internal contradictions it faces (Dussouy 2010a: 143). By doing so, Dussouy attempts to offer a "...methodology for gathering data that can serve as the basis for an empiric-inductive theory" (Cohen 2010: 163).

This instrumentalist approach to modelling seems well suited to the construction of actors' preferences in the Arctic territorial dispute for three major reasons. First, the bredth of its scope allows the researcher to capture the multi-dimensional geopolitical reality of the Arctic region - a reality that cannot be properly reflected either by the classical approach to geopolitics, nor by its (recent) critical alternative. ${ }^{18}$ Second, it is a relatively simple method of systematization that can operate on any geographic scale (local - regional - global)

16 The amount and origin of empirical data.

17 A special issue of Geopolitics (vol. 15, no. 1, 2010) was devoted to Dussouy's model and its evaluation by top global specialists on geopolitics and international relations such as Alexander Murphy, Saul Cohen, and Robert Jervis.

18 Classical geopolitical theory insists on either total geographical determinism (Ratzel, Kjellen, Haushofer - the German School) or nearly total geographic determinism (Mahan, Mackinder, Spykman - the Anglo-Saxon School), while (poststructuralist) critical geopolitics instead tends to focus too much on the role of cultural and social aspects of power in international relations (Ó Tuathail, Agnew, Dalby). 
and is based on a solid number of axioms that have been widely accepted in academic literature (Cohen 2010: 157-160). Third, it allows us to re-construct the power of a state and reveal its capability constraint. The biggest problem with this approach is that Dussouy neither defines the variables representing the geopolitical configuration in the model, nor provides any hint on how to operationalize these variables.

As "the lines between international economics and regional economics are becoming blurred" (Krugman 1993: 8), it is appropriate to position the Arctic provinces within both regional and international contexts. We operationalize the variables that are assumed to constitute the 'core' of geopolitical analysis by Aymeric Chapraude (2007), Guyla Csurgai (2009) and Patrice Gourdin (2010) to reconstruct the power relations in the Arctic region. ${ }^{19}$

\section{Dataset}

The Updated Arctic Regional Attributes Dataset (ARA Dataset) ${ }^{20}$ is presented in Appendix $\mathrm{A}^{21}$ in Excel 2010 format. It is a cross-national dataset of eight cases (all Arctic states - permanent members of the Arctic Council) covering seventeen variables. Balancing between the costs of data compilation and the need to generate credible results, the dataset does not include all data for a 20-year period but instead contains information from the selected databases that is taken once every five years, starting in 1990 and ending in 2010. Following Tom Sniders, we work with time series: the Arctic (or any) geopolitical configuration can be observed at a number of discrete time points, under the assumption

19 Aymeric Chapraude defines geopolitical analysis as the study of the 'desire for power' of states in relation to its physical and human geographical characteristics. The power of a state is assumed to depend on two factors: geographic conditions (both material geographical position and discursive geographical representations of populations) and absolute strength (qualitative and quantitative human, military and economic factors) - Chauprade (2007): 17. Patrice Gourdin defines power as capability (a capability to act, a capability to make others act; a capability to prevent others from acting; a capability to refuse to act) and focuses on thirty factors, divided into four categories: Territory (maps, geographical situation, mountains-valleys, climate, vegetation, natural resources, cities-towns-villages, boundary symbols), Population (demography; ethnic, linguistic, religious, socio-economic, cultural and tribal or clan-related dividing lines; and political rivalries), Representations (symbolic places, national sentiments, disputed elements of history, resistance against oppression, messianic tendencies and desire for power), and External actors ('Friend and Foe' reasoning, economic interests, territorial claims, international obligations, strategic objectives, regional power ambitions, non-state actors that operate within the law, and illegal non-state actors) - Gourdin (2010): 248-262. Similarly to Aymeric Chapraude, Guyla Csurgai believes that any geopolitical system consists of both constant and variable components, and have objective and subjective components: elements of physical geography, availability of natural resources, boundary specifics, ethnic composition and demography, socio-economic factors, the question of identity, geopolitical representation and historical heritage - Csurgai (2009): 48, 51.

20 The description of the original ARA Dataset can be found in Valko, Irina. "Differentiating Arctic Provinces: A Cluster Analysis of Geographic and Geopolitical Indicators." Central European Journal of International and Security Studies, vol. 8, no. 2 (2014).

21 Appendix $A$ is available upon request. 
that there exists an unobserved evolution occurring between these time points (Snijders 2005: 215).

Three indicators (Lo_Lan, Reg_Co and History) are the author's analytical inventions, and the rest has been imported from the eight Arctic states' national statistical databases, circumpolar database ArcticStat, Encyclopedia Britannica, CIA - World Factbook, Weatherspark: Weather Dashboard, Sea Around Us Project, DaftLogic: Advanced Google Maps Distance Calculator, OANDA Historical Exchange Rates Database, Bartsits (2000) and the SIPRI Military Expenditure Dataset. Some variables have been standardized in order to eliminate nation-specific scaling differences. The detailed description of data aggregation is provided in Appendix B. ${ }^{22}$ What follows is a brief description of four categories of power potential. ${ }^{23}$ Each Arctic state's regional capability power potential is characterized by a mix of strength coming from the following geopolitical sub-systems:

Physical potential - non-weighted average of national capability arising from the Arctic geo-physical features:

- Area (thou. sq. km) ${ }^{24}$ - the sum of all polar land area (including inland water and glaciers) delimited by provincial boundaries and/or coastlines, as defined in the respective sub-national administrative division of the Arctic states. The variable is configured at constant 2010 values throughout the entire period studied.

- $\quad$ EEZ (thou. sq. $\mathrm{km})^{25}$ - the existing maritime delimitation of the region; recalculated for each Arctic province according to the length of its coastline facing the northernmost ocean. Data for Iceland, Greenland, the Faroe Islands, Svalbard, Jan Mayen and Alaska (Arctic sea basin-only) are imported from the Sea around Us Project. In all other cases, the EEZ per province is unknown. The available data is therefore transformed using basic algebra. First, we find the length of coastline $(\mathrm{km})$ and area of the EEZ (km sq) for each Arctic state. Second, we 'reconstruct' precisely the same length of coastline for each Arctic state in DaftLogic: Advanced Google Maps Distance Calculator to overcome the coastline paradox. ${ }^{26}$ We refer to the same maps and markers to

22 Appendix B is available upon request.

23 In most cases, the variables are defined according to their specification in the codebooks for the related datasets. Those interested in the exact configuration of all variables should therefore refer to the original documentation found in aforementioned public datasets.

$24<$ www.arcticstat.org $>$, <www.britannica.com $>$, <www.gks.ru $>$

$25<$ www.seaaroundus.org/eez/>, <www.gks.ru $>$, <wediscovercanada.ca $>$, <www.seaaroundus.org/ eez/>, <www.daftlogic.com/projects-advanced-google-maps-distance-calculator.htm\#loginbox >

26 Due to the fractal-like properties of coastlines, the length of the coastline depends on the method used to measure it. 
calculate the share of the coastline of the Arctic state polar province in relation to the country's total coastline. Third, we recalculate the country's total Arctic basin-related EEZ according to the percentile value of the provincial coastline. Fourth, we sum all polar provinces' results to obtain the total EEZ generated by the Arctic coastline of the eight states. The variable is configured at constant values throughout the entire studied period.

- $\quad t$ Jan. and $t$ Jul. (average, $\left.{ }^{\circ} \mathrm{C}\right)^{27}$ - the average temperature ${ }^{28}$ registered at thirty-seven weather stations located within the Arctic Circle. If data at several stations in the Arctic province is available we take a simple average.

- Lo-Lan (binary) - variable describing relative proximity strength on land: $1=$ the air distance $(\mathrm{km})$ between a state capital city and regional capital(s) is smaller than between regional capital(s) and the Geographic North Pole $\left(90^{\circ} \mathrm{N}\right)$. For each Arctic actor, the weighted average of results for all polar provinces is calculated; $0=$ the air distance $(\mathrm{km})$ between a state capital city and regional capital(s) (administrative center(s) of polar provinces) is greater than between regional capital(s) and the Geographic North Pole $\left(90^{\circ} \mathrm{N}\right)$; The variable is configured at constant values throughout the entire period under consideration.

Socio-economic potential - non-weighted average of national capability determined by the demographic and economic features of the Arctic:

- Pop and Ind_Pop (thou.persons) ${ }^{29}$ - the total number of residents (citizens and non-citizens), and total number of indigenous residents, of Arctic states as of January 1 of the respective year. All data are standardized. Data for Sweden, Norway, Finland, Canada and Russia are averaged.

- $\quad G R P(m \ln . U S D)^{30}$ - Gross Regional Product, by polar province, by year, in current prices, summed for the Arctic state. The data have been standardized. National currencies have been converted into current USD using OANDA yearly-average historical currency exchange rates.

\footnotetext{
27 <weatherspark.com>

28 Due to the significant heterogeneity in the extent of seasonal temperature scattering across Arctic provinces, the annual average temperature is not as informative as bi-annual average temperatures.

$29<w w w$. arcticstat.org >; <www.statcan.gc.ca >; <www.stat.fi ; <www.ssb.no>; <www.census.gov>; Hugo Ahlenius, et al. (ed.), Vital Arctic Graphics: People and Global Heritage on our Last Wild Shores (Arendal: UNEP/GRID, 2010), accessed March 14, 2015, http://www.grida.no/publications/vg/arctic/, p. 15 $30<$ www.arcticstat.org $>$, <www.oanda.com/currency/historical-rates>
} 
No data is available for Newfoundland and Labrador, Quebec (2000, 2010); Finnmark, Nordland, Tromso, Norrbotten, Vasterbotten (2010). These values are therefore predicted. We first judge, via the construction of a scatterplot, whether the available time range forms a trend. If they do, we predict the missing value using multiple regression analysis. Only significant results with 95 per cent probability are included. ${ }^{31}$

- Agric. (mln. USD) ${ }^{32}$ - the share of agriculture, forestry, fishing, and hunting within the Gross Regional Product, by province, by year, recalculated according to percentile value for every respective year, summed for the Arctic state. The missing data on Nunavut, Northwest Territories and Yukon in 2010 is reconstructed in the same way as in the case of GRP.

- Ind. (mln. USD) $)^{33}$ - the share of mining, manufacturing (metal products, electronics, machinery and scientific instruments, shipbuilding, pulp and paper, foodstuffs, chemicals, textiles, and clothing) and energy and water supplies, within the Gross Regional Product, by province, by year, recalculated according to a percentile value for every respective year, summed for the Arctic state. The missing data on Nunavut, Northwest Territories and Yukon in 2010 has been reconstructed by the same method used in the case of GRP.

- Serv. $(m \ln \text {. USD })^{34}$ - the share of construction, wholesale and retail trade, transportation, information, finance, real estate, tourism, education, healthcare and social services within the Gross Regional Product, by province, by year, recalculated according to the percentile value for every respective year, summed for the Arctic state. The missing data on Nunavut, Northwest Territories and Yukon in 2010 has been reconstructed by the same method used in the case of GRP.

Military potential - non-weighted average of national capability determined by the region's security configuration:

- Reg_MB (number) ${ }^{35}$ - active permanent military installations (land bases, including training centres, maintenance sites, surveillance bases, air bases and heliports, naval bases, Coast and Home Guard

31 Significance level $=0.05 ;$-value $<0.05$.

$32<$ www.arcticstat.org>

$33<w w w . a r c t i c s t a t . o r g>$

$34<w w w . a r c t i c s t a t . o r g>$

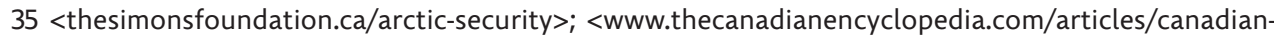
-forces-bases >; <www.fmn.dk/eng/allabout/Pages/TasksintheArcticandtheNorthernAtlantic.aspx>; <http://www.puolustusvoimat.fi/en/>; <http://mil.no/organisation/about/norwegianmilitarybases/ Pages/default.aspx>; <www.strategicstudiesinstitute.army.mil/pdffiles/PUB1073.pdf $>;<$ http://www. forsvarsmakten.se/en/Organisation/The-Swedish-Army/>; <http://www.princeton.edu/ achaney/tmve/ 
and sledge patrol bases) located within the borders of the Arctic states' polar provinces. A land base is defined as a military installation with a personnel of at least 18 persons. A naval base as a military installation with at least one armed vessel. An air base as a military installation with a runway of at least $1600 \mathrm{~m}$ ( $45 \times 40 \mathrm{~m}$ in case of heliport). Data on Khanty-Mansii and Yamal-Nenets provinces of Russia are unavailable.

- Reg_Co (number of active links) ${ }^{36}$ - the number of Arctic states' active membership in any of the following military integration frameworks: North Atlantic Treaty Organization; Memorandum of understanding between the Ministry of Defence of the Kingdom of Denmark, the Ministry of Defence of the Republic of Finland, the Ministry of Defence of the Kingdom of Norway, and the government of the Kingdom of Sweden concerning Nordic Coordinated Arrangement for Military Peace Support; and the North American Aerospace Defense Command. We codify national advancement in regional institutionalized military integration according to the following scale: $0=$ no active link, $1=$ one active link, 2 = two active links; with no intention of reflecting the intensity ('depth') of integration. ${ }^{37}$ Each province of the Arctic state, including the the Arctic provinces, is assumed to share all national-level opportunities and responsibilities granted by the given integration frameworks.

- Exp_1 (mln. 2011 USD) ${ }^{38}$ - the data on regional military expenditures is unavailable, so we work with national data that is taken from the SIPRI Military Expenditure Dataset. We consider the military expenditure of Canada, Denmark, Finland, Iceland, Norway, Russian Federation, Sweden, and the United States in 2000, 2005 and 2010, in million constant 2011 USD.

Symbolic potential (power of geopolitical representations) - non-weighted average of national capability in the system's ideational and subjective space:

wiki100k/docs/Military_of_Iceland.html>; Siemon T. Wezeman, "Military Capabilities in the Arctic," Background Paper (Stockholm: SIPRI, March 2012).

36 Valko 2013: 104, 109.

37 Coding the intensity ('depth') of institutionalized integration is a challenging task: in contrast to economic regionalism, wherein a range of approaches to typifying regional economic integration frameworks exist (e.g. Telo 2008), without operationalization algorithms, no template for evaluation of military regionalism is available.

38 <milexdata.sipri.org/files/?file=SIPRI+military+expenditure+database+1988-2012.xlsx> 
- Exp_2(number $)^{39}$ - share of military spending as percent of Gross Domestic Product, for each Arctic state, for each respective year.

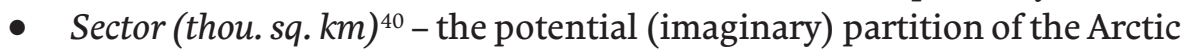
Ocean. Finland and Sweden are non-littoral states - their coastlines do not directly face the Arctic Ocean. Simultaneously, Iceland does not have an active claim over the High North, even though part of its EEZ is located north of the Arctic Circle. Zero values are assigned in all three cases.

- History (binary) $)^{41}$ - the strength of historical affiliation of each Arctic actor to the polar landmass and waters. We assign value 1 if an existing state sovereignty has been manifested and/or formed in the $18^{\text {th }}$ century or the $19^{\text {th }}$ century. A zero value is assigned if that happened in the $20^{\text {th }}$ century. The variable is configured at constant 2010 values throughout the entire period under consideration.

\section{Measurement}

After defining the parameters of the power potential assessment we set up a measurement algorithm. There are $m$ Arctic states and $n$ indicators for each Arctic state, so a matrix of values $x_{i, j}, i=1 \ldots, m ; j=1 \ldots, n$ can be constructed. At a given level of approximation, for a number of reasons, ${ }^{42}$ equal weights are granted to sub-indices within the aggregate index. The matrix of sub-indices $I_{i, j}, i=1 \ldots, m ; j=1 \ldots, n$ can be found with [2]:

$$
I n_{i, j}=\frac{x_{i, j}-\min _{1 \leq j \leq n} x_{i, j}}{\max _{1 \leq j \leq n} x_{i, j}-\min _{1 \leq j \leq n} x_{i, j}}, i=1, \ldots, m ; j=1, \ldots, n .
$$

The value of each index $I_{i, j}, i=1 \ldots, m ; j=1 \ldots, n$ varies from 0 to 1 . A value that is close to 0 is proximate to the minimal value, while being close to 1 signals proximity to the maximum value. The aggregate index $C I_{i}, i=1 \ldots, m$ is a mean of the indices $I_{i, j}, i=1 \ldots, m ; j=1 \ldots, n$, according to [3]:

$$
C I n_{i}=\frac{1}{n} \sum_{j=1}^{n} \operatorname{In}_{i, j}
$$

$39<$ ilexdata.sipri.org/files/?file=SIPRI+military+expenditure+database+1988-2012.xlsx>.

40 Bartsits 2000.

41 Hough 2013.

42 Because geopolitical theory does not offer the model for evaluating the 'weight' of specific dimensions within the complex geopolitical system, we refer to the basic assumption of the inferential logic: we assume no variation in this weight. The analysis of the results of the empirical test allows for the initial assumption to be modified, based on any quasi-experimental research design template. 
The aggregate index varies from 0 to 1 . If $C \operatorname{CI}_{i}=0$, all sub-indices $\operatorname{In}_{i, j}, j=1 \ldots, n$ are equal to zero, i.e. all indicators have the lowest values. In contrast, if $\mathrm{CI} n_{i}=$ 1 , all sub-indices $I n_{i, j}, j=1 \ldots, n$ are equal to 1, i.e. all indicators have the highest values. Then, we calculate the percentile share of each Arctic state's aggregate power index $C C n i, \mathrm{i}=1 \ldots, m$, where $m$ is the number of parameters in the system, multiplied by 100 , as in [4]:

$$
C C n_{i}=100 \frac{C I n_{i}}{\sum_{j=1}^{m} C I n_{j}}, i=1, \ldots, m
$$

In this case, the sum of all indices $C C n_{i}, i=1 \ldots, m$ is equal to 1 :

$$
\sum_{i=1}^{m} C C n_{i}=1
$$

Finally, we consider the polar capability constraint of each state, $\mathrm{Zn} n_{i}$, to be an inversed aggregate power potential, i.e. aggregate weakness [5]:

$$
\mathrm{Zn} n_{i}=1-C C n_{i}
$$

\section{Russia's Polar Capability Constraint}

We now turn to the results of the application of the aforementioned measurement procedure to the data from the Updated ARA Dataset. Figure 2 demonstrates the evolution of the aggregate polar capability indices for the eight Arctic states. Axis $x$ represents moments in time, while axis $y$ represents the actual value of polar capability (the latter varies from 0 to 1 ). Figure 3 demonstrates the inverse situation: axis $x$ represents the same time shots, but axis $y$ now shows the significance of resource constraint in the Arctic system (the latter again varies from 0 to 1). It is apparent from both graphs that, throughout the period studied, the geopolitical strength of the Arctic states can be grouped into two internally homogeneous clusters. We label the first cluster as 'Russia and Canada'. These two countries share a unique combination of geographical, economic, military, demographic and institutional integration capabilities not found elsewhere in the region. On the one hand, as of 2010, Russian and Canadian polar provinces occupy almost 80 percent of the region's land (and roughly one half of the EEZ in the northernmost ocean), 87 percent of the Arctic population, and 56 percent 
of military installations in the region, and approximately 80 percent of gross regional product (53 percent of agricultural product, 84 percent of industrial product and 81 percent of services).

Canada and Russia also generate slightly above half of the symbolic connections in the region. On the other hand, their cumulative military strength reaches 'only' 36 percent of the total capability in the region. The polar capability constraints of Russia and Canada are the lowest in the region: throughout the period under consideration, this constraint for Russia and Canada varies from 0,2 and 0,46 in 1990 to 0,3 and 0,39 in 2010, respectively.

All other Arctic states, including the remaining two players of the Arctic sovereignty game, Denmark and the United States, belong to the second cluster, which we call "the Rest of A8". Aside from the aggregate military potential, which can be explained by an extremely high value for national military spending in the United States, and physical geography domain, where the aforementioned grouping is not as evident as in other dimensions of social power base, none of these countries is able to reach a fifty-percent share of total capability in the region. Russia's capability constraint varies from 0,2 in 1990 (minimum value) to 0,37 in 1995 (maximum value), so there is a non-zero variation range $[0,37-0,2=0,17]$. The second hypothesis is therefore falsified.

Figure 2: Agent-based aggregate polar capability (1990-2010)

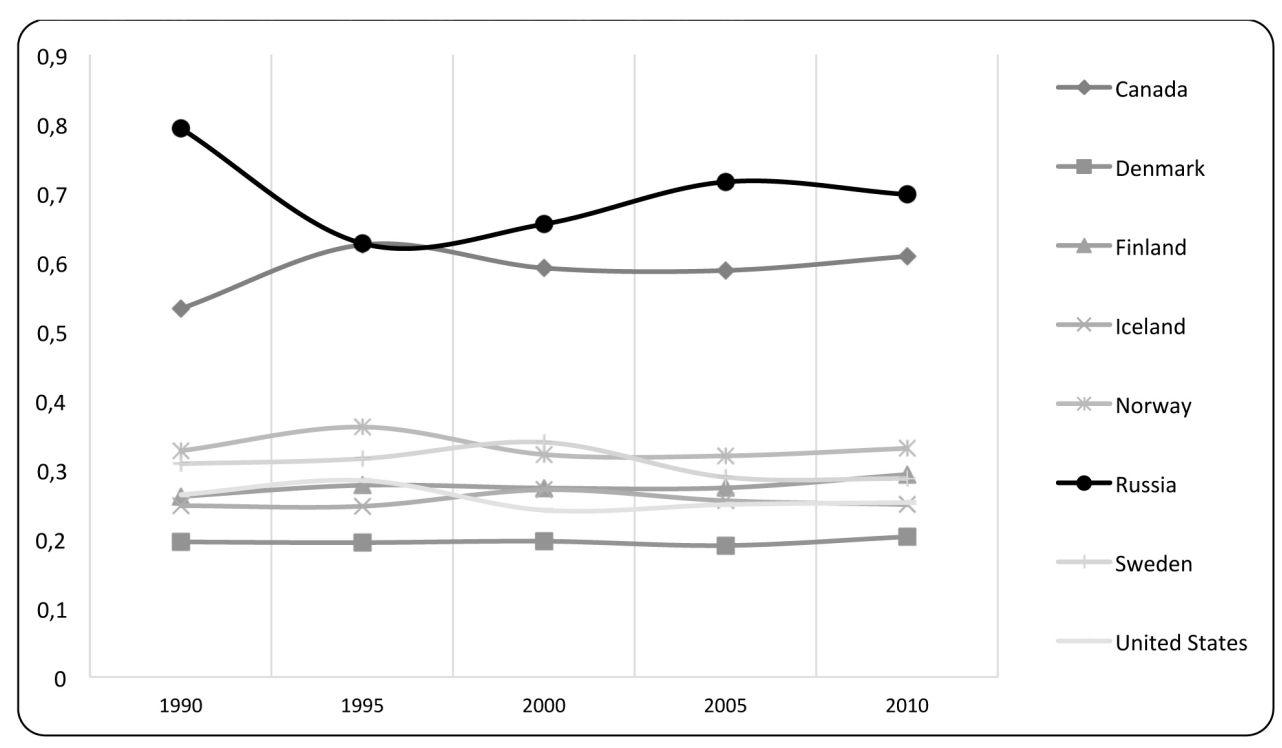

Source: author. 
Because the aggregate index blurs the distinction between individual geostrategic action spaces (we assign the same weight to all four categories of regional strength) it is important to analyse the evolution of regional power in each dimension of state power. Figure 4 demonstrates the differentiated, dimension-specific power capability of Russia, in contrasted with the other Arctic states. Russia's physical geographic characteristics make it a leader in the geo-physical action space, mainly due to having the largest land area and EEZ beyond the Arctic Circle. As the values of the majority of variables belonging to this category have been fixed, ${ }^{43}$ no significant variation in the domain can be observed. A/ The Minor variation is due to the 20 -year variation in the mean temperature. ${ }^{44}$

\section{Figure 3: Polar capability constraint (1990-2010)}

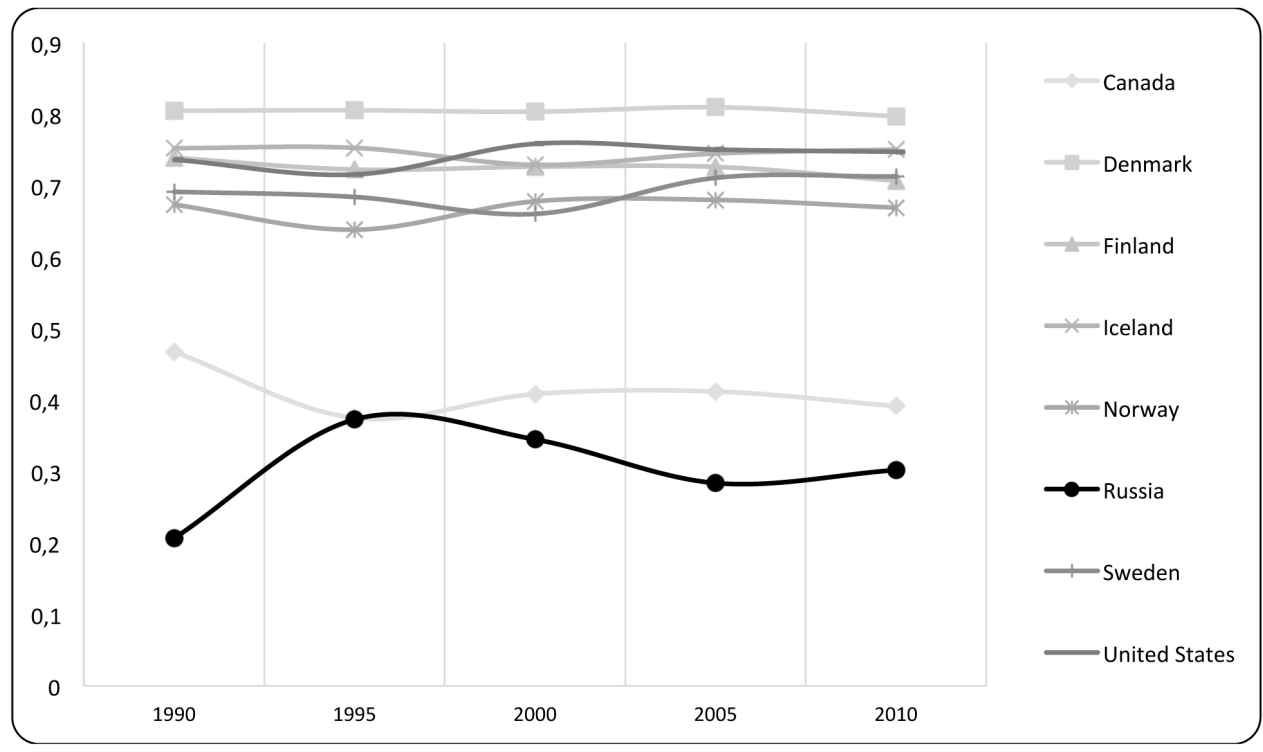

Source: author.

In contrast, the socio-economic domain is a source of 'turbulence' in Russia's aggregate polar capability. These variations are mainly due to the changing values of gross regional product - the result of the domestic economic recession of the mid-1990 s (the culmination of the effects of market reforms) and of 1998. Another reaction to the collapse of the USSR can be observed via the gradual decrease in Russia's military capability in the Arctic. Even though this drop is slightly corrected in 2000, it still does not reach the level of 1990 . The main

43 See Section 2. 1.

44 Because we study only a twenty-year period, temperature variations are not significant. 
reason for such a 'poor' result is in the simultaneous interplay of two factors in which Russia cannot outbid the opponents: regional military integration frameworks in which the country does not participate, and its current military spending, which is not the highest in the region.

These two factors outweigh the fact that Russia has the largest number of regular military installations in the region. Finally, with the largest national sector claim in the Arctic Ocean, and with the second highest military spending (measured as a percent of gross domestic product) - just after the United States - Russia is a continuous leader in the regional symbolic power domain. The worsening of Russia's position in this last domain is mainly due to the sharp drop in military spending, from 12.3 percent of GDP in 1990 to 3.6 percent in 2000-2005.

Figure 4: Dimension-specific polar capability

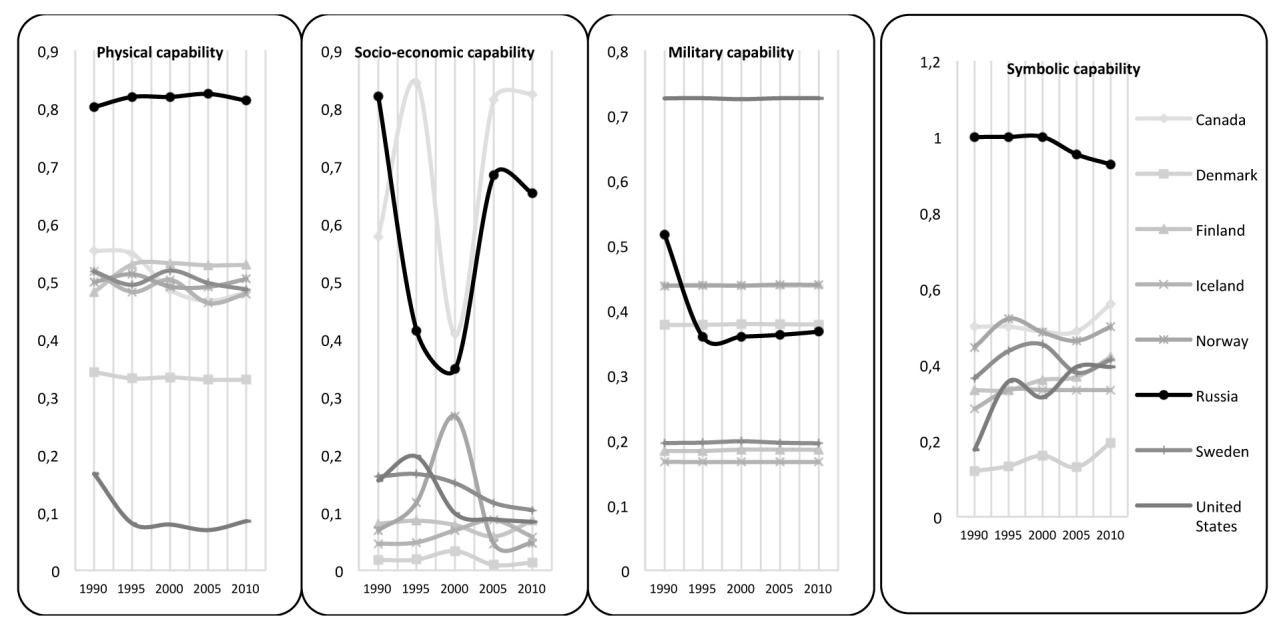

Source: author.

\section{In Place of Conclusion: Implications for Russia's Arctic Strategy}

This analysis differentiates the Arctic states according to seventeen specific attributes, in order to identify the relative geopolitical strength of Russia in the Arctic sovereignty game as determined by its regional (material and virtual) resource base, and to determine whether this strength forms a stable trend throughout the period studied. The analysis of the aggregate polar capability constraint has divided the eight Arctic states into two distinct clusters ('Russia and Canada' and 'the Rest of A8') with the former representing the most powerful actors in the region and the latter representing the weaker actors. Despite 
popular rhetoric on the major 'weakening' of Russia in $1990 \mathrm{~s}$ due to the period of socialism-to-capitalism transition, the ranking of Russia among all Arctic states according to its power configuration in the Arctic has not changed dramatically, even though some fluctuations can be observed in socio-economic and military geostrategic action spaces in 1995 and 2000. In 2010, Russia remains the most powerful Arctic actor due to the lowest value of its polar capability constraint. The first hypothesis is therefore confirmed. At the same time, the aggregate power grouping is unstable throughout the period under consideration. A non-zero variation range is observed in the evolution of Russia's polar capability constraint, hence the second hypothesis is falsified.

Returning to Arthur Lykke's 'chair metaphor', can we suggest the preference formation framework for Russia in the Arctic sovereignty game based on the evolution of its polar capability constraint (i.e., Russia's strategic means)? If we know the resource base of a given actor, can we theorize on the appropriate mix of concepts and objectives?

In this specific situation, Russia is considered to be a rational decision maker: while choosing whether or not to act, it relies on cost-benefit analysis and attempts to maximize the expected utility. Imported from neoclassical economics, perfect rationality implies a purposeful calculation of all strategic options, subject to the constraints of technology and endowments. But, due to information asymmetry and time constraint, the decision makers in the social world are not able to calculate everything. In order to overcome this problem we follow the economists whose approach is summarized by one of the most respected specialists in methodology of economic research, Mark Blaug:

In common parlance, rationality means acting with good reasons and with as much information as possible or, in somewhat more formal terms, consistently applying adequate means to achieve well-specified ends. For the economist, however, rationality means choosing in accordance with a preference ordering that is comlete and transitive, subject to perfect and costlessly acquired information; where there is uncertainty about future outcomes, rationality means maximizing expected utility, that is, the utility of an outcome multiplied by the probability of occurrence (1992: 229).

The instrumental definition of strategy from a national perspective as described by Yanger (2010) allows, for the purpose of future research on Russian policy in the Arctic, to rank preferences over the alternative scenarios (options) prior to running the polar sovereignty game. Preferences might be properly ranked if the following conditions are satisfied: decision makers order alternatives in terms of their preferences and they know the intensity of their preference; the order of preference is transitive (if A is preferred to B and B is preferred to C, then $\mathrm{A}$ is preferred to $\mathrm{C}$ ); decision makers always select the strategy that yields the highest expected utility and the lowest costs (i.e., they opt to act only if the 
expected gains are larger than the expected losses) and they consider alternative means of achieving desirable ends in terms of the product of the probability of achieving alternative outcomes and the utility associated with those outcomes refer to Bueno de Mesquita's expected-utility model for formal mathematical notation of these assumptions (1989: 144). Based on these assumptions, in aggregate terms, Russia (and, to a lesser extent, Canada) is best 'equipped' with polar resources since its polar capability constraint is the lowest in the region. Russia is the most powerful actor in the Arctic sovereignty game: in contrast to all other Arctic states, Russia may allow itself to intensify own goals (i.e. be able to set more ambitious objectives) and use more coercive means to achieve them.

It is much more rational for Russia to be the first to start moving the dispute into a new state of equilibrium (either alone or in functional coalition with other players) than for any other Arctic actor.

The results of this study provide a diagnostic, preliminary map of the geostrategic balance in the Arctic, and the geostrategic importance of the polar vector of Russian foreign policy is steadily growing in modern Russia. It is important to understand whether the periods of major dimension-specific fluctuations (culminating in 2000) which serve, in fact, as evidence that Russia's capability constraint does not form a stable trend throughout the period studied, are due to the inconsistency of raw input into the dataset, or because there exists a hidden geopolitical development which is not evident at the current stage of analysis. It is also crucial to ascertain whether the observable differentiation of all Arctic states into stronger and weaker players is altered by the introduction of additional indicators of regional development. Finally, the positivist research design, the dataset and the measurement procedure (which is based, among others, on the horizontal approach to the weights of all specific dimensions in the complex system) have certain limitations, so the next step would be to obtain data on other aspects of geopolitical developments in the region (among others, the structure-implied capabilities of the Arctic states, as the centrality in the network of economic, military and demographic inter- and intra-regional material and virtual exchange), and to support current findings by other analytical approaches (regression-based techniques, qualitative analysis) and, to complete the picture, to develop a framework for strategic interactions between all Arctic players in the polar sovereignty game based on polar capability constraint, in the same way as it has been done here for Russia. 


\section{References}

\section{Primary sources}

ArcticStat. Available at: www.arcticstat.org.

CIA World Factbook. Available at: www.cia.gov/library/publications/the-world-factbook/ fields/2012.html.

Daft Logic: Advanced Google Maps Distance Calculator. Available at: www.daftlogic.com/projects-advanced-google-maps-distance-calculator.htm\#loginbox.

Encyclopedia Britannica. Available at: www.britannica.com.

Finnish Defence Forces. Available at: www.puolustusvoimat.fi/en/.

International Borders Research Unit "Maritime jurisdiction and boundaries in the Arctic region." Available at: www.dur.ac.uk/ibru/resources/arctic.

Norwegian Armed Forces. Available at: mil.no/organisation/about/norwegianmilitarybases/ Pages/default.aspx.

OANDA Historical Exchange Rates Database. Available at: www.oanda.com/currency/historical-rates

Rosstat. Available at: www.gks.ru.

Sea Around Us Project. Available at: www.seaaroundus.org/eez/.

SIPRI Military Expenditure Dataset. Available at: milexdata.sipri.org/files/?file=SIPRI+military+ expenditure+database+1988-2012.xlsx.

Statistics Canada. Available at: www.statcan.gc.ca.

Statistics Finland. Available at: www.stat.fi.

Statistics Greenland. Available at: www.stat.gl.

Statistics Iceland. Available at: www.statice.is.

Statistics Norway. Available at: www.ssb.no.

Statistics Sweden. Available at: www.scb.se.

Statistiska centralbyrån. "Kust och stränder i Sverige." MI 50 SM 1301. Sveriges officiella statistik / Statistiska meddelanden, 2013. Available at: www.scb.se/statistik/MI/MI0812/2012A01/ MI0812_2012A01_SM_MI50SM1301.pdf.

Swedish Armed Forces. Available at: www.forsvarsmakten.se/en/Organisation/The-Swedish-Army. UNCLOS. Full text of the Convention is available at: http://www.un.org/depts/los/convention_agreements/texts/unclos/closindx.htm.

U.S. Census Bureau. Available at: www.census.gov.

Weather Dashboard. Available at: weatherspark.com. 


\section{Secondary sources}

Ahlenius, Hugo, et al. (ed.). Vital Arctic Graphics: People and Global Heritage on our Last Wild Shores. Arendal: UNEP/GRID, 2010. Available at: http://www.grida.no/publications/vg/arctic/ (15 April 2015).

Bartsits, I. O pravovom statuse rossijskogo arkticheskogo sektora." Pravo i politika \# 12, 2000 (In Russian: Барциц, И. “О правовом статусе российского арктического сектора," Право и политика № 12, 2000); p. 1+. Available at: http://geo.1september.ru/view_article. php?id=200700102 (15 April 2015).

Blaug, Mark. The Methodology of Economics: Or how economists explain. Cambridge: Cambridge University Press, 1992.

Bueno de Mesquita, Bruce (1989): The Contribution of Expected-Utility Theory to the Study of International Conflict. in Manus I. Midlarsky. Handbook of War Studies. Boston: Unwin Hyman.

Bueno de Mesquita, Bruce (2010): Foreign Policy Analysis and Rational Choice Models. R. A. Denemark. in The International Studies Encyclopedia. International Studies Association.

Chauprade, Aymeric (2007): Géopolitique: Constantes et changements dans l'histoire. Paris: Ellipses Marketing.

Cohen, Saul (2010): Evaluating Systemic Geopolitics - A Twenty-First Century View. Geopolitics 15 (1): 157-164.

Csurgai, Gyula (2009): Constant and Variable Factors of Geopolitical Analysis. in Gyula Csurgai. Geopolitics: Schools of Thought, Method of Analysis and Case Studies. Geneva: Editions de Penthes, 48-86.

Dussouy, Gerard (2010): Systemic Geopolitics: A Global Interpretation Method of the World. Geopolitics 15 (1): 133-150.

Gourdin, Patrice (2010): Géopolitiques: Manuel pratique. Paris: Choiseul Editions.

Grygiel, Jakub (2006): Great Powers and Geopolitical Change. Baltimore: Johns Hopkins University Press.

Hough, P. (2013): International Politics of the Arctic: Coming in from the Cold. New York: Routledge.

Knell, Niave (2008): Reemergence of the Arctic as a Strategic Location. Fort Leavenworth (Kansas): School of Advanced Military Studies, United States Army Command and General Staff College.

Krugman, Paul R. (1993): Geography and Trade. Cambridge MA: MIT Press.

Lykke, Arthur et al. (2001): U. S. Army War College Guide to Strategy. Carlisle: Strategic Studies Institute, United States Army War College.

Malhotra, Deepak Four Strategies for Making Consessions. Research and Ideas. Harvard Business School, Working Knowledge, 6 March 2006; 1+. Available at: http://hbswk.hbs.edu/item/5235. html (15 April 2015).

Murphy, Alexander (2010): Gerard Dussouy's Systemic Geopolitics. Geopolitics 15 (1): 151-156. 
Plokhotnikov, Konstantin (2012): Metod i iskusstvo matematicheskogo modelirovaniya: kurs lektciy. Moskva: Flinta, 2012 (In Russian: Плохотников, Константин. Метод и искусство математического моделирования: күрс лекций. Москва: Флинта, 2012).

Snijders, Tom A. B. (2005): Models for Longitudinal Network Data. in Peter J. Carrington, John Scott and Stanley Wasserman. Models and Methods in Social Network Analysis. Cambridge: Cambridge University Press.

Strandsbjerg, Jeppe (2012): Cartopolitics, Geopolitics and Boundaries in the Arctic. Geopolitics 17 (4): 818-842.

Valko, Irina (2013): The Arctic Regional System under External Influence: The Case of China. in Martin Riegl and Jakub Landovský. Strategic and Geopolitical Issues in the Contemporary World. Newcastle upon Tyne: Cambridge Scholars Publishing, 94-118.

Valko, Irina (2014): Differentiating Arctic Provinces: A Cluster Analysis of Geographic and Geopolitical Indicators. Central European Journal of International and Security Studies 8 (2).

Wezeman, Siemon T. (2012): Military Capabilities in the Arctic" Background Paper. Stockholm: SIPRI.

Yarger, H. Richard (2010): Art Lykke and the US Army War College Strategy Model. in Boone Bartholomees U.S. Army War College Guide to National Security Issues, Vol. 1: Theory of War and Strategy, edited by. Carlisle: Institute of the US Army War College, July 2010; 45-52.

Mgr. et Mgr. Irina Valko is a, Ph.D. Candidate and lecturer at the Department of Political Science, Institute of Political Studies, Faculty of Social Sciences, Charles University in Prague. Her dissertation project, entitled "Applicability of systemic analysis to the study of the geostrategic importance of the transborder political region - the Arctic case" investigates the possibility of integrating the logic of neoclassical geopolitical theory and quantitative research methodology in order to reflect the contemporary and future geostrategic equilibrium in the Arctic regional system. Her research interests include the use of quantitative approaches to the study of political science, polar geopolitics, transformation of the system of international relations and new regionalism. Postal address: U Křže 8/10, 158 00, Prague 5, Czech Republic. E-mail:valko@fsv.cuni.cz. 